\title{
Serum Calcitonin Gene-Related Peptide and Receptor Protein Levels in Patients With Fibromyalgia Syndrome: A Cross-Sectional Study
}

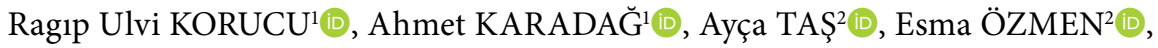 \\ Emrullah HAYTA $^{3}{ }^{D}$, Yavuz SILIG ${ }^{2}{ }^{-1}$
}

${ }^{1}$ Department of Physical Medicine and Rehabilitation, Cumhuriyet University Faculty of Medicine, Sivas, Turkey

${ }^{2}$ Department of Biochemistry, Cumhuriyet University Faculty of Medicine, Sivas, Turkey

${ }^{3}$ Department of Physical Medicine and Rehabilitation, Acıbadem University Faculty of Medicine, Istanbul, Turkey

\begin{abstract}
Objectives: This study aims to compare the serum calcitonin gene-related peptide (CGRP) and CGRP receptor protein levels between patients with fibromyalgia syndrome (FM) and healthy control subjects.

Patients and methods: The study included 88 patients ( 7 males, 81 females; mean age $44.5 \pm 9.1$ years; range, 20 to 72 years) newly-diagnosed with FM according to the 2010 American College of Rheumatology criteria and 88 healthy volunteers ( 6 males, 82 females; mean age $43.0 \pm 6.1$ years; range, 20 to 57 years). Venous blood samples were collected from both groups for the measurement of the levels of serum CGRP and CGRP receptor proteins (receptor component protein [RCP], receptor activity modifying protein 1 [RAMP 1] and calcitonin receptor-like receptor [CLR]).

Results: A comparison of the serum CGRP, CLR and RCP levels of the FM and control groups revealed a statistically significant difference ( $p=0.001$, $p=0.005, p=0.001$, respectively). The difference between the groups in respect of the serum RAMP 1 levels was not statistically significant ( $p=0.107$ ). Conclusion: The serum CGRP, CLR and RCP levels were found to be higher in the FM patients, but no difference was determined between the FM patients and the healthy control group in respect of the RAMP 1 level. These results can be of guidance for further clinical studies of the etiopathogenesis and treatment of FM.

Keywords: Calcitonin gene-related peptide, fibromyalgia, pain, receptor proteins.
\end{abstract}

Fibromyalgia syndrome (FM) is a clinical condition with many symptoms such as diffuse pain, fatigue, sleep disturbance and cognitive dysfunction. ${ }^{1}$ Genetic, environmental factors, immunological factors, peripheral and central mechanisms are thought to play a role in the pathogenesis of $\mathrm{FM}^{2}{ }^{2}$ In previous clinical studies, it has been suggested that dysfunction in pain processing mechanisms such as peripheral and central sensitization may play a role in FM pathogenesis, and the allodynia and hyperalgesia seen in FM patients are thought to be due to this dysfunction in central mechanisms..$^{3,4}$ However, central sensitization, which is thought to play a role in FM pathogenesis, is responsible for the increase in excitatory neurotransmitters such as calcitonin gene-related peptide (CGRP), glutamate and substance $\mathrm{P}$, or a decrease in inhibitory neurotransmitters such as serotonin and norepinephrine..$^{5-7}$

Received: August 27, 2019 Accepted: November 02, 2019 Published online: February 07, 2020

Correspondence: Ahmet Karadağ, MD. Cumhuriyet Üniversitesi Tıp Fakültesi Fiziksel Tıp ve Rehabilitasyon Anabilim Dalı, 58140 Sivas, Türkiye. Tel: +90 506 - 5335456 e-mail:dr_ahmetkaradag@hotmail.com Syndrome: A Cross-Sectional Study. Arch Rheumatol 2020;35(4):463-467. 
Calcitonin gene-related peptide is a 37 amino acid peptide primarily localized in the A delta and C nerve fibres. ${ }^{8}$ CGRP is one of the excitatory neurotransmitters involved in the transmission of pain and central sensitization. Together with CGRP, CGRP receptor plays an important role in peripheral and central sensitization. ${ }^{9}$ A functional CGRP receptor requires three components; the calcitonin receptor-like receptor (CLR), which consists of seven transmembrane domains, the receptor activity modifying protein 1 (RAMP 1), which grants specificity for binding with CGRP, and receptor component protein (RCP), which appears to be critical for signal transduction by promoting effective coupling to the Gs protein. ${ }^{9}$

There are studies in the literature evaluating the relationship between CGRP and pain in different diseases. ${ }^{10}$ However, although there is chronic pain in FM, to the best of our knowledge, there is no study in the literature that has evaluated serum CGRP levels in FM. However, evaluation of the serum level of CGRP alone may not be sufficient to understand the role of CGRP in the pathogenesis of FM. Therefore, evaluation of CGRP and the CGRP receptor protein system is important for better understanding of the role of CGRP in FM. In this study, we aimed to compare the serum CGRP and CGRP receptor protein levels between patients with FM and healthy control subjects.

\section{PATIENTS AND METHODS}

This cross-sectional study was conducted in the Physical Medicine and Rehabilitation Clinic of Sivas Cumhuriyet University Medical Faculty between June 2018 and June 2019. The study included 88 patients ( 7 males, 81 females; mean age $44.5 \pm 9.1$ years; range, 20 to 72 years) who were newly-diagnosed with FM according to the 2010 American College of Rheumatology ${ }^{11}$ criteria and 88 healthy control subjects $(6$ males, 82 females; mean age 43.0 \pm 6.1 years; range, 20 to 57 years). FM patients with malignancy, rheumatic disease (osteoarthritis, Behçet's disease, rheumatoid arthritis, etc.) and those with a known history of systemic disease (hypertension, diabetes mellitus, neurological or psychiatric disease, etc.) were excluded. The control group was formed of subjects with no known disease and no medication use, recruited from hospital personnel and the relatives of patients. The sample size of study was calculated with prevalence calculation when the mean of population and standard deviation values were not known. The study protocol was approved by the Cumhuriyet University Clinical Research Ethics Committee (approval no: 2018-03/25, dated: 26.03.2018). A written informed consent was obtained from each participant. The study was conducted in accordance with the principles of the Declaration of Helsinki.

The sex and age of the participants were recorded. Venous blood was collected from the patient and control groups. Venous blood samples were taken at 08:00-10:00 after an eight-hour fast. The samples in anticoagulant tubes were centrifuged at $3,000 \mathrm{rpm}$ for five minutes at $+4^{\circ} \mathrm{C}$, then the separated serum was stored at $-30^{\circ} \mathrm{C}$ to measure serum CGRP, CLR, RAMP 1 and RCP levels. Human CGRP, CLR, RAMP 1 and RCP levels were measured with enzyme-linked immunosorbent assay kits (Sunredbio, catalogue nos: 201-12-1062, 201-127854, SRB-T-85538, 201-12-4742, respectively) according to the manufacturer's instructions (Sunred Biological Technology Co., Ltd, Shanghai, China).

\section{Statistical analysis}

Data obtained in the study were analyzed statistically using the IBM SPSS Statistics version 22.0 software (IBM Corp., Armonk, NY, USA). Conformity of the data to normal distribution was analyzed using the Kolmogorov-Smirnov test. A Mann-Whitney $\mathrm{U}$ test was applied when the parametric test assumptions could not be met. Categorical data were compared using the chi-square test. Data were expressed as number and percentage or as mean/median \pm standard deviation values. A value of $\mathrm{p}<0.05$ was considered statistically significant. Considering the $3.6 \%$ prevalence rate of FM in Turkey, ${ }^{12}$ and the total population of the province, 88 patients were included in the study within a $95 \%$ confidence interval. The power of the study was calculated post-hoc and found to be $90.14 \%$. 


\begin{tabular}{|c|c|c|c|c|c|}
\hline & \multicolumn{2}{|c|}{ FM group $(\mathrm{n}=88)$} & \multicolumn{2}{|c|}{ Control group $(n=88)$} & \multirow[b]{2}{*}{$p$} \\
\hline & Median & IQR & Median & IQR & \\
\hline CGRP (ng/mL) & 22.65 & 1.55 to 104.95 & 3.06 & 0.01 to 22.25 & $0.001^{*}$ \\
\hline CLR (pg/mL) & 3.96 & 2.75 to 7.36 & 3.07 & 2.24 to 4.71 & $0.005^{*}$ \\
\hline $\mathrm{RCP}(\mathrm{pg} / \mathrm{mL})$ & 322.95 & 185.96 to 538.99 & 2.01 & 0.01 to 123.88 & $0.001^{*}$ \\
\hline RAMP $1(\mathrm{pg} / \mathrm{mL})$ & 612.58 & 456.91 to 912.32 & 656.20 & 120.1 to 896.78 & 0.107 \\
\hline
\end{tabular}

\section{RESULTS}

No statistically significant difference was determined between the patient and control groups in terms of age and sex ( $p>0.05)$. When the CGRP levels of the FM patients and the control group were compared, the serum CGRP level was statistically significantly higher in the FM group than in the control group $(p=0.001)$. In the comparisons of the serum CLR, RCP and RAMP 1 levels, the CLR and RCP levels were statistically significantly higher in the FM group than in the control group $(p=0.005$, $p=0.001$, respectively). No statistically significant difference was determined between the groups in respect of serum RAMP 1 levels $(p=0.107)$ (Table 1).

\section{DISCUSSION}

In this study, the serum CGRP and CGRP receptor components, CLR, RCP and RAMP 1 levels were evaluated in patients with FM, and the serum CGRP levels were found to be higher in patients with FM than in healthy individuals. In addition, CGRP receptor proteins CLR and RCP levels were found to be higher in patients with FM, whereas the RAMP 1 level was not different from that of healthy individual.

Calcitonin gene-related peptide modulates motor, sensory and integration systems in the central nervous system, and provides pain awareness and has an excitatory effect by increasing the release of substance P. Peripherally, however, it regulates synaptic transmission by inhibiting the expression of acetylcholine esterase at the neuromuscular junction. ${ }^{13}$
Since CGRP is a neurotransmitter responsible for the development of peripheral and central sensitization, CGRP levels have been evaluated in many clinical trials particularly in those related to migraine. ${ }^{10}$ CGRP levels have been reported to be high particularly in studies conducted on the musculoskeletal system and rheumatic diseases. Onuoha and Alpar ${ }^{14}$ showed that serum CGRP level was higher in patients with muscle injury compared to the control group. In another study, Alpar et al. ${ }^{15}$ showed high serum CGRP levels in patients with neck and shoulder pain. In a different study, Dong et al. ${ }^{16}$ determined that the serum CGRP level was higher in patients with knee osteoarthritis than in healthy control subjects. In a review evaluating the relationship between CGRP and arthritis, CGRP levels were reported to be higher in patients with arthritis. ${ }^{17}$ Birklein et al. ${ }^{18}$ showed that the serum CGRP level was higher in patients with complex regional pain syndrome compared to a control group. In different clinical studies, it has been shown that CGRP levels are high in patients with neuropathic pain. ${ }^{19}$ In a previous study, CGRP levels in cerebrospinal fluid were measured in patients with FM, but no comparisons were made because there was no healthy control group. ${ }^{20}$ In the current study, the serum CGRP level was high in patients with FM, as in other musculoskeletal diseases.

Although there are many receptor components of CGRP, the main receptor functioning for CGRP is accepted as CLR/RAMP $1 .{ }^{21}$ However, to be able to see the optimal function of CLR/RAMP 1 receptor, RCP is necessary. ${ }^{22}$ While CLR is expressed widely throughout the body, specific expression of RAMPs to tissue is known. ${ }^{23,24} \mathrm{RCP}$ is known to be expressed together with $\mathrm{CGRP}^{25}$ and previous clinical 
studies have shown that CGRP receptor level is increased in migraine, and inflammatory and neuropathic pain. Again, different studies have shown that CGRP receptors are high in synovial examinations of patients with osteoarthritis. ${ }^{26-29}$ To the best of our knowledge, there is no study in the literature that has evaluated serum CGRP receptor levels in FM. However, the results of the current study of FM patients, similar to those of previous studies of different disease groups, found high levels of CLR and RCP, which are CGRP receptor components. Unlike previous studies, the serum RAMP 1 level of the patients in the current study was not found to be different from that of the control group. The reason for this different result was thought to be that RAMP 1, which is a CGRP receptor, is expressed specifically to tissue.

Limitations of this study included the lack of objective pain level measurement and lack of correlation between pain level and CGRP level.

In conclusion, serum CGRP level and CLR and RCP levels, which are components of CGRP receptor, were found to be higher in patients with FM than in healthy subjects. However, the level of RAMP 1, which is a CGRP receptor component in FM patients, was no different from that of healthy individuals. The results of this study may contribute to a better understanding of the pathogenesis of FM, and can serve as a guide for future clinical studies investigating the pathogenesis and treatment of FM. Nonetheless, there is a need for further clinical studies to evaluate the level of serum CGRP and CGRP receptor proteins in FM.

\section{Declaration of conflicting interests}

The authors declared no conflicts of interest with respect to the authorship and/or publication of this article.

\section{Funding}

This study was supported by the Scientific Research Project Fund of Cumhuriyet University (project No. T788).

\section{REFERENCES}

1. Metyas S, Rezk T, Arkfeld D, Leptich T. Autoinflammation and immunomodulation in inflammatory fibromyalgia syndrome- a review. Curr Rheumatol Rev 2017;13:98-102.
2. Albrecht PJ, Rice FL. Fibromyalgia syndrome pathology and environmental influences on afflictions with medically unexplained symptoms. Rev Environ Health 2016;31:281-94.

3. Gracely RH, Geisser ME, Giesecke T, Grant MA, Petzke F, Williams DA, et al. Pain catastrophizing and neural responses to pain among persons with fibromyalgia. Brain 2004;127:835-43.

4. Cassisi G, Sarzi-Puttini P, Casale R, Cazzola M, Boccassini L, Atzeni F, et al. Pain in fibromyalgia and related conditions. Reumatismo 2014;66:72-86.

5. Staud R, Smitherman ML. Peripheral and central sensitization in fibromyalgia: pathogenetic role. Curr Pain Headache Rep 2002;6:259-66.

6. Ablin J, Neumann L, Buskila D. Pathogenesis of fibromyalgia - a review. Joint Bone Spine 2008;75:273-9.

7. Bellato E, Marini E, Castoldi F, Barbasetti N, Mattei L, Bonasia DE, et al. Fibromyalgia syndrome: etiology, pathogenesis, diagnosis, and treatment. Pain Res Treat 2012;2012:426130.

8. Maggi CA. Tachykinins and calcitonin gene-related peptide (CGRP) as co-transmitters released from peripheral endings of sensory nerves. Prog Neurobiol 1995;45:1-98.

9. Iyengar S, Ossipov MH, Johnson KW. The role of calcitonin gene-related peptide in peripheral and central pain mechanisms including migraine. Pain 2017;158:543-59.

10. Walsh DA, McWilliams DF. CGRP and Painful Pathologies Other than Headache. Handb Exp Pharmacol 2019;255:141-67.

11. Wolfe F, Clauw DJ, Fitzcharles MA, Goldenberg DL, Katz RS, Mease P, et al. The American College of Rheumatology preliminary diagnostic criteria for fibromyalgia and measurement of symptom severity. Arthritis Care Res (Hoboken) 2010;62:600-10.

12. Topbas M, Cakirbay H, Gulec H, Akgol E, Ak I, Can G. The prevalence of fibromyalgia in women aged 20-64 in Turkey. Scand J Rheumatol 2005;34:140-4.

13. Rossi SG, Dickerson IM, Rotundo RL. Localization of the calcitonin gene-related peptide receptor complex at the vertebrate neuromuscular junction and its role in regulating acetylcholinesterase expression. $\mathrm{J}$ Biol Chem 2003;278:24994-5000.

14. Onuoha GN, Alpar EK. Calcitonin gene-related peptide and other neuropeptides in the plasma of patients with soft tissue injury. Life Sci 1999;65:1351-8.

15. Alpar EK, Onuoha G, Killampalli VV, Waters R. Management of chronic pain in whiplash injury. $\mathrm{J}$ Bone Joint Surg [Br] 2002;84:807-11.

16. Dong T, Chang H, Zhang F, Chen W, Zhu Y, Wu T, et al. Calcitonin gene-related peptide can be selected as a predictive biomarker on progression and prognosis of knee osteoarthritis. Int Orthop 2015;39:1237-43.

17. Walsh DA, Mapp PI, Kelly S. Calcitonin generelated peptide in the joint: contributions to pain and 
inflammation. Br J Clin Pharmacol 2015;80:965-78.

18. Birklein F, Schmelz M, Schifter S, Weber M. The important role of neuropeptides in complex regional pain syndrome. Neurology 2001;57:2179-84.

19. Schou WS, Ashina S, Amin FM, Goadsby PJ, Ashina M. Calcitonin gene-related peptide and pain: a systematic review. J Headache Pain 2017;18:34.

20. Vaerøy H, Sakurada T, Førre O, Kåss E, Terenius L. Modulation of pain in fibromyalgia (fibrositis syndrome): cerebrospinal fluid (CSF) investigation of pain related neuropeptides with special reference to calcitonin gene related peptide (CGRP). J Rheumatol Suppl 1989;19:94-7.

21. Chang CL, Hsu SYT. Development of chimeric and bifunctional antagonists for CLR/RAMP receptors. PLoS One 2019;14:e0216996.

22. Evans BN, Rosenblatt MI, Mnayer LO, Oliver KR, Dickerson IM. CGRP-RCP, a novel protein required for signal transduction at calcitonin gene-related peptide and adrenomedullin receptors. J Biol Chem 2000;275:31438-43.

23. Hagner S, Haberberger RV, Overkamp D, Hoffmann $\mathrm{R}$, Voigt KH, McGregor GP. Expression and distribution of calcitonin receptor-like receptor in human hairy skin. Peptides 2002;23:109-16.
24. Russell FA, King R, Smillie SJ, Kodji X, Brain SD. Calcitonin gene-related peptide: physiology and pathophysiology. Physiol Rev 2014;94:1099-142.

25. Dickerson IM. Role of CGRP-receptor component protein (RCP) in CLR/RAMP function. Curr Protein Pept Sci 2013;14:407-15.

26. Ji Y, Rizk A, Voulalas P, Aljohani H, Akerman S, Dussor G, et al. Sex differences in the expression of calcitonin gene-related peptide receptor components in the spinal trigeminal nucleus. Neurobiol Pain 2019;6:100031.

27. Uzan B, Ea HK, Launay JM, Garel JM, Champy R, Cressent $\mathrm{M}$, et al. A critical role for adrenomedullincalcitonin receptor-like receptor in regulating rheumatoid fibroblast-like synoviocyte apoptosis. J Immunol 2006;176:5548-58.

28. Minatani A, Uchida K, Inoue G, Takano S, Aikawa $\mathrm{J}$, Miyagi $\mathrm{M}$, et al. Activation of calcitonin generelated peptide signaling through the prostaglandin E2-EP1/EP2/EP4 receptor pathway in synovium of knee osteoarthritis patients. J Orthop Surg Res 2016;11:117.

29. Barwell J, Wootten D, Simms J, Hay DL, Poyner DR. RAMPs and CGRP receptors. Adv Exp Med Biol 2012;744:13-24. 